\title{
History of the Sedimentary Infilling of Yarimburgaz Cave, Turkey
}

\author{
William R. Farrand and Jill P. McMahon \\ Geological Sciences, University of Michigan, Ann Arbor, \\ Michigan 48109-1063
}

\begin{abstract}
Yarimburgaz is a double cave with slightly offset upper and lower entrance chambers, connected laterally inside the cave. Below Byzantine and modern debris, the upper cave encloses Chalcolithic to Upper Paleolithic occupations above a beach sand attributed to the Last Interglacial. Below the beach sand, strongly modified sediments contain sparse Lower Paleolithic artifacts. The lower cave preserves only Lower Paleolithic industries, but with abundant cave bear and other fauna. Lower cave sediments ( $>5 \mathrm{~m}$ thick) comprise a lower, barren section of decalcification clays interfingering with alluvial fine sands, small gravel and rounded pebbles from the cave interior, and isolated limestone blocks from the cave ceiling. These sediments have been strongly affected by secondary phosphatization that fills vugs, cements the sediments, and produces thick reaction rinds on the large blocks. The upper $2 \mathrm{~m}$ of the fill becomes more rocky as the evidence of human and bear utilization of the cave becomes prominent. No habitation structures or hearths were detected in the lower cave. ESR and uranium-series dating suggests an age between $>160$ and 390 ka for the lower cave occupations. Apparently the cave was wide open to the exterior at that time. The final phase of filling was characterized by abundant angular limestone blocks, suggestive of earthquake disturbance. () 1997 John Wiley \& Sons, Inc.
\end{abstract}

\section{INTRODUCTION}

Yarimburgaz Cave is located about $20 \mathrm{~km}$ west of the center of Istanbul, a short distance north of the Istanbul international airport, and about $12 \mathrm{~km}$ north of the Sea of Marmara (Figure 1). Scientific exploration in Yarimburgaz Cave dates to the mid-19th century, and some attempts at excavation.were made in the 19:20s (Kansu, 1970). Systematic excavation was begun by Ozdogan in 1986 (Ozdogan and Koyunlu, 1986), largely in the upper cave. Our excavations in the lower cave in 1988, 1989, and 1990 were under. the direction of F. Clark Howell (University of California-Berkeley) and Guven Arsebuk (Istanbul University), with a team of Turkish students, and financial support from the National Geographic Society. Arsebuk (1993) provides a recent summary.

\section{DESCRIPTION OF THE CAVE}

The cave system (Figures 1 and 2) consists of two passages; the longer, lower passage penetrates about $500 \mathrm{~m}$ into the limestone ridge, but the shorter, higher one reaches a dead end only $50 \mathrm{~m}$ from the present entrance. 


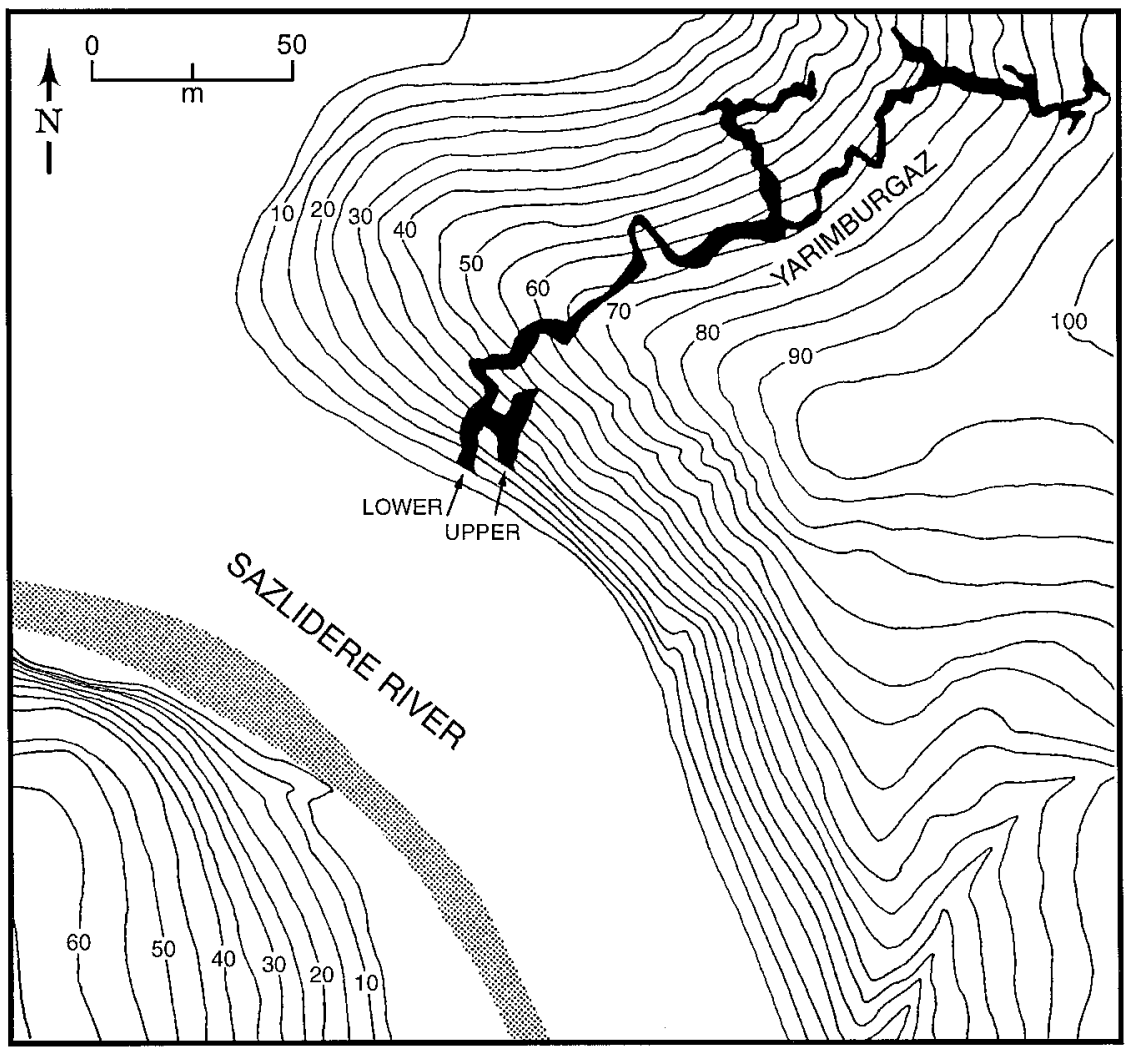

Figure 1(a). Topographic map of the vicinity of Yarimburgaz Cave, showing the location of the cave (in black) within the hill adjacent to the Sazlidere valley. Five-meter contour interval.

A short transverse corridor connects the two longer passages, sloping down from the upper to the lower cave about $25 \mathrm{~m}$ inside the cave. The mouths of the two passages are, respectively, 11.5 and $18.6 \mathrm{~m} / \mathrm{sl}$ and face southward overlooking the Sazlidere valley, the marshy floodplain of which is only about $1 \mathrm{~m}$ above sea level.

The lower passage is still an active karstic cave, with growing speleothems and pools of standing water in its dark, inner recesses. Evidence of running water exists in the form of rounded quartz and chert pebbles and stratified sand on the cave floor. These exotic materials indicate that an insurgence exists (or existed in the past) in the inner reaches of the cave. We excavated similar deposits in Lower Paleolithic levels in the outer part of the lower passage, as described below. Also, deposits of very fine silt and clay occur in the active portion of the cave, especially where lateral karstic conduits join the main passage. These fine deposits appear to be reworked surface soil or 


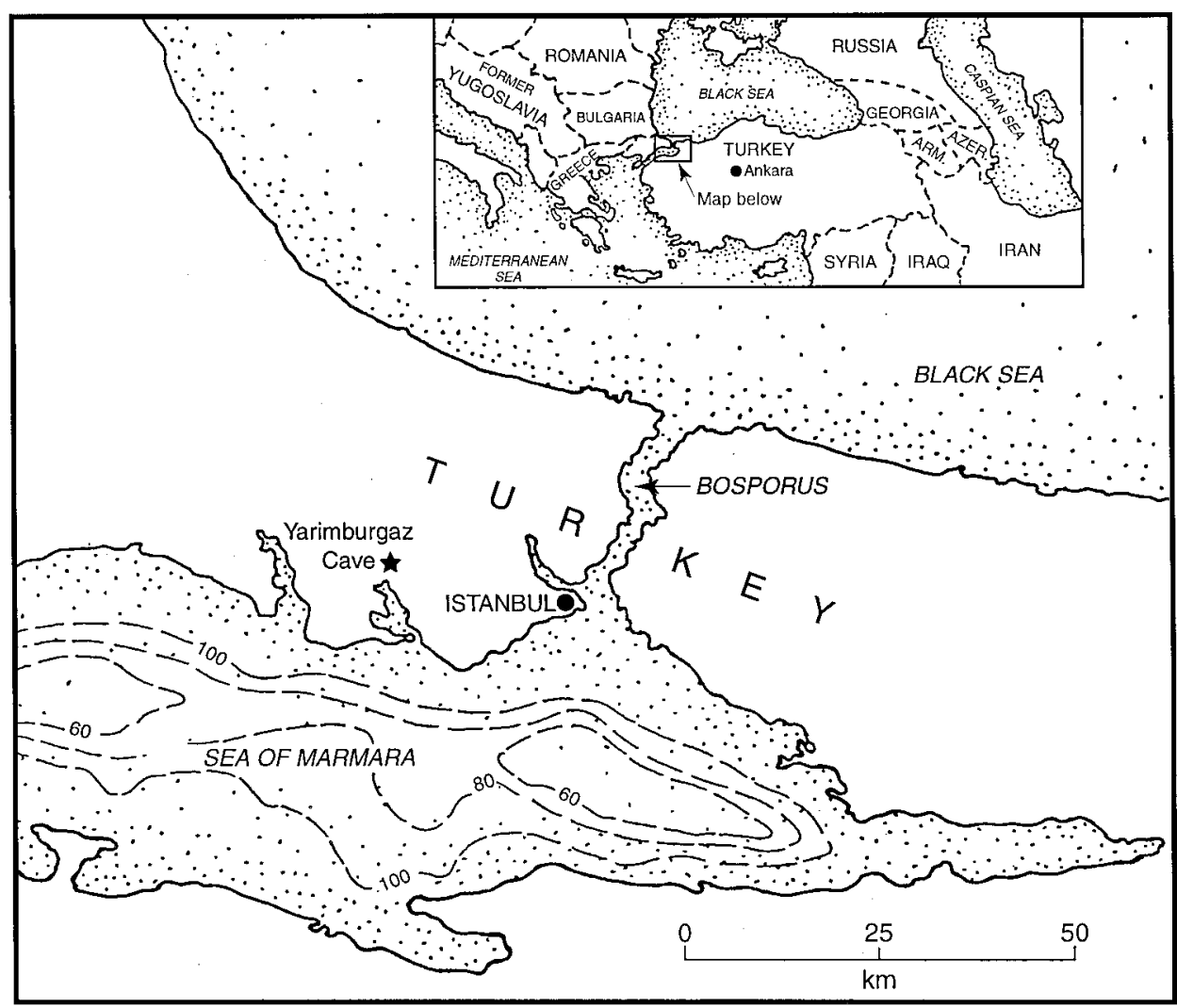

Figure 1(b). Location map showing the relation of Yarimburgaz Cave to Istanbul and the Sea of Marmara.

decalcification clays washed in from other parts of the karstic system. Again, they have counterparts in the Lower Paleolithic deposits.

The upper cave was strongly modified in Byzantine times when a church was carved into its walls, and a monastery constructed outside the cave mouth. These modifications removed prehistoric deposits to an undetermined extent, but some Chalcolithic and Upper Paleolithic deposits remain. The lower cave was also disturbed by illicit excavators or treasure seekers. Modern pits as deep as 2 or $3 \mathrm{~m}$ were revealed in our excavations, and any evidence of prehistoric deposits intermediate in age between the Lower Paleolithic and the modern, mixed debris is missing, that is, Middle/Upper Paleolithic and Chalcolithic, which are present in the upper cave.

We believe that both the upper and lower passages formerly continued out beyond their present mouths at the times of the Lower Paleolithic occupations, when the Sazlidere valley had not been eroded as deeply as now. We 
FARRAND AND MCMAHON

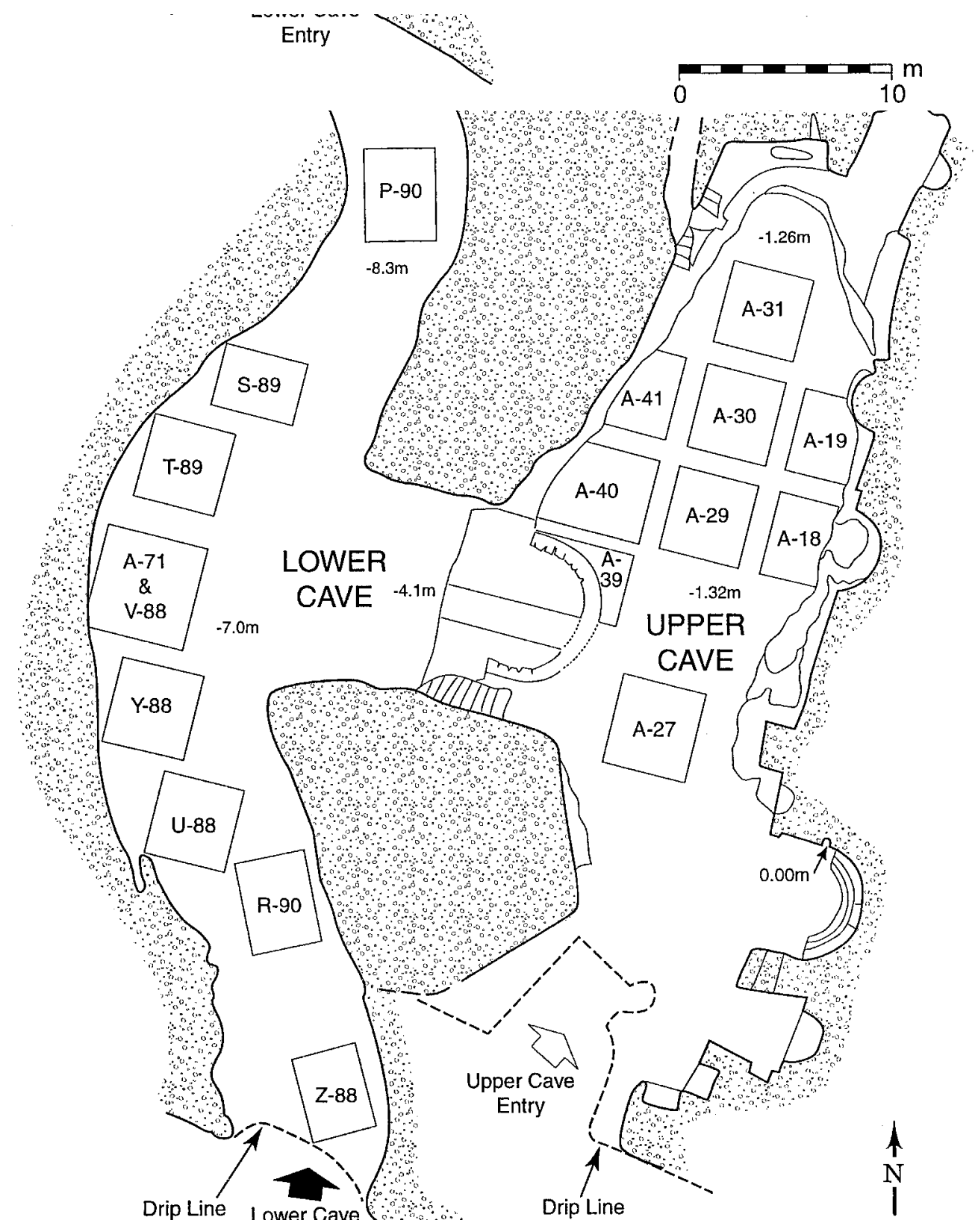

Figure 2. Plan of the outer part of Yarimburgaz cave, showing the upper and lower entrance chambers and the excavated trenches. 
found no prehistoric remains in the vicinity of the modern drip line, in the area where one expects rather intense human utilization of a cave. On the other hand, erosion of preexisting cave sediments was very clearly in evidence at the mouth of the lower passage (our Trench Z-88).

The deepest trench (V-88 in the lower cave, adjacent to Ozdogan's A.71 trench) reached $5 \mathrm{~m}$ below the present floor of the lower cave, but the lowest $3 \mathrm{~m}$ appear to be barren of artifacts or bones. We did not reach bedrock at any point along the central axis of the lower cave.

\section{ARCHAEOLOGICAL RESULTS}

Study of the artifacts (Kuhn, 1995), large mammals and taphonomy (Stiner, 1995) and microfauna (Santel, 1994) is continuing, and, therefore, the information reviewed here is tentative and preliminary. A brief note on the materials recovered in the upper cave was published by Ozdogan and Koyunlu (1986). Chalcolithic finds were mostly sherds, but also included a few stone tools, and marine and freshwater mollusks. Below the Chalcolithic, sparse flint and quartzite artifacts (about 30 total) occurred along with an abundance of charcoal lenses or fragments in Levels 6 and 7. Most of the stone objects are nondiagnostic utilized or retouched flakes or chunks, but a few of them show traces of Levallois preparation. However, radiocarbon dates obtained by Ozdogan and ourselves place them in a final Paleolithic or early Neolithic time frame (Table II).

In the lower cave, Lower Paleolithic artifact assemblages occur immediately below the modern disturbance. These include cores and flakes, some retouched or utilized, along with pebble tools and chopping tools (Figure 3), and moderate-to-large unworked cobbles, catalogued as manuports. Bifacial retouch is very uncommon, and there are no standardized large tools, such as handaxes, cleavers, or trihedrals. Raw materials include quartz, quartzite, and chert, but we found no local source of these materials other than the small cobbles that underlie the local river floodplain and pebbles entrained through the karstic passages of the lower cave, mentioned above.

More than 1600 artifacts were recovered, mostly from the first $2 \mathrm{~m}$ below the floor of the lower cave (Strata X, W, and V) (see Table I). A few enigmatic cobbles, possible manuports, occurred between 2 and $2.5 \mathrm{~m}$ depth (Strata U and $\mathrm{T}$ ) along with a few herbivore bones. We found neither bones nor artifacts below $2.5 \mathrm{~m}$ depth, and no evidence of the presence of fire in the Lower Paleolithic sediments of the lower cave. However, the question of fire must be reevaluated in light of the studies of Schiegl et. al. (1996), who have identified diagenetic products of wood ash where no visible evidence of hearths remain.

Bones were very abundant in the upper levels of the lower cave, especially bones of cave bear, Ursus deningeri. A preliminary list of herbivores includes Equus caballus, Sus scrofa, Dama, Capreolus, Megaceros, Bos/Bison, Gazella, and Capra. Carnivores, other than cave bear, were Canis (2 spp.), Vulpes, Panthera (2 spp.), Felis (2 spp.), and Crocuta. The microfauna is not very rich 

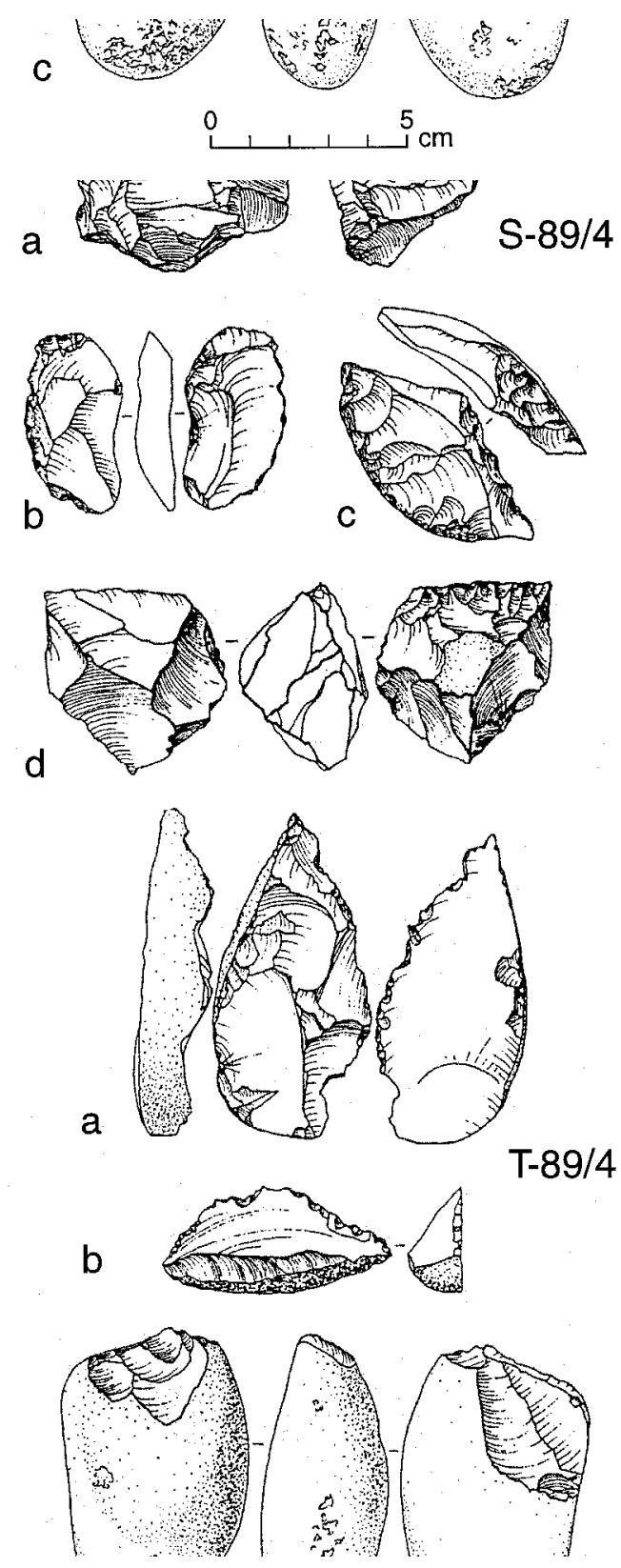

Figure 3. A sampling of artifacts from the Lower Paleolithic industry of Trenches S-89 and T89, lower cave, Yarimburgaz. Top row, a quartz core; second row, denticulate side scrapers on flint; third row, a thick cortical flake with microdenticulate retouch; fourth and fifth rows, naturally backed knives on flint; bottom row, a combination chopper and hammerstone on quartzite (after Kuhn, 1995). 


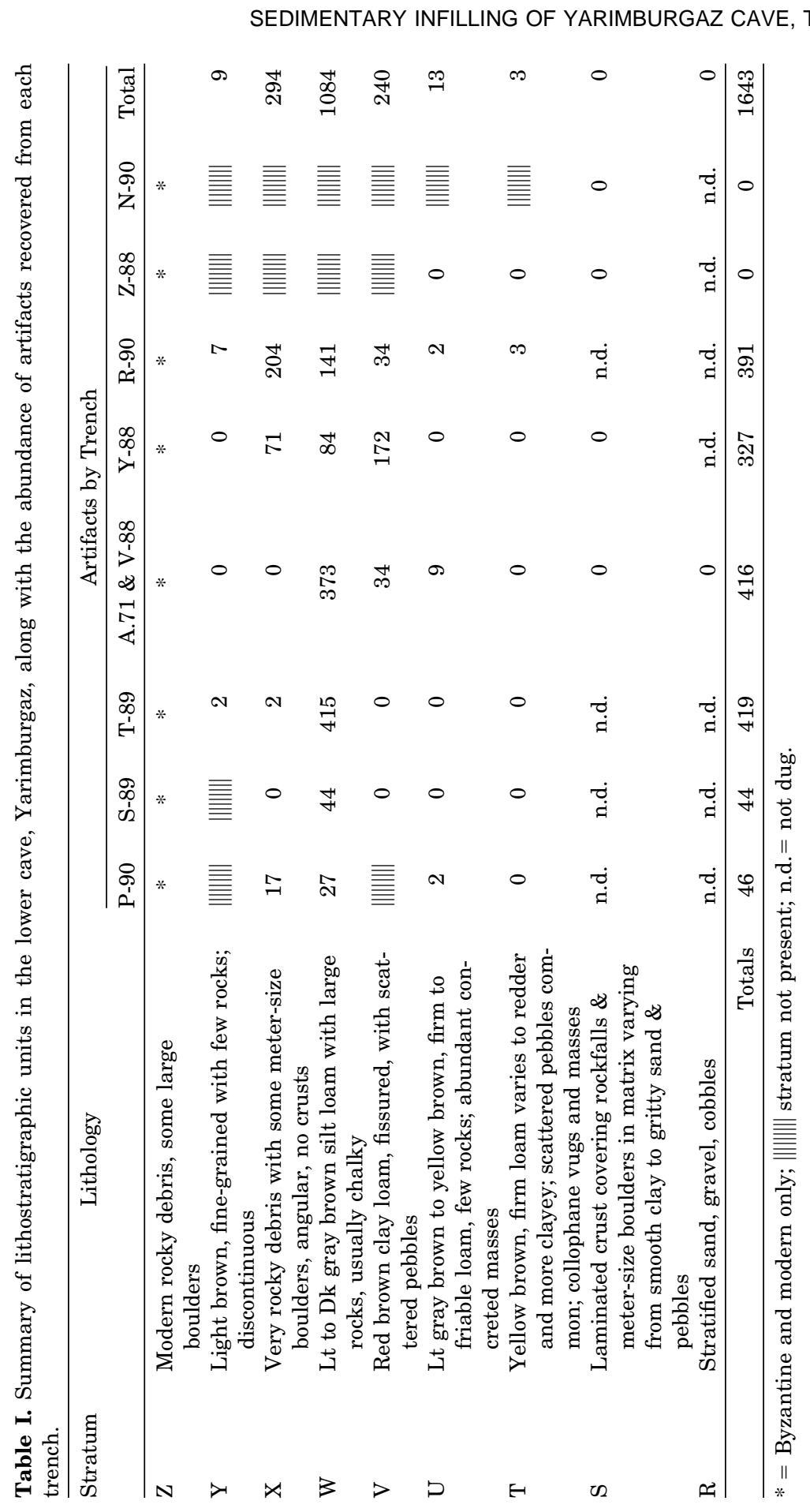


or diverse, comprising mostly bats, a few lagomorphs, some Sciurids, Cricetids, Arvicolids, Murids, Spalax, insectivores and Glirids. Samples for pollen analysis have been collected and are awaiting analysis.

The cave may have alternated between a human habitat and a cave bear habitat. The co-occurrence of bones and artifacts and the apparent clustering of bones and stones on certain "living floors" argues strongly for human utilization of the cave. In fact, human artifacts and animal bones always co-occur, except in Trench Y-88, Level 5 (= Stratum S) where several carnivores and their prey(?) were found without any trace of human activity. To date, the only human fossil found in the cave is an unworn, robust incisor (left $\mathrm{I}_{2}$ ) from Level 1c in Y-88.

\section{GEOARCHAEOLOGICAL OBSERVATIONS}

In 1989 and 1990 the authors examined the sections exposed by the excavators, collected sediment and micromorphology samples, and began a stratigraphic synthesis of the deposits in both the lower and upper caves. Sediment study by McMahon is in progress, and some preliminary results are reported here. Charcoal for radiocarbon dating was collected from the upper cave. ESR dating of cave bear teeth and uranium-series dating of travertine is being conducted by Schwarcz and Blackwell (Blackwell et al., 1990, 1995). Geomorphological observations of the terrain surrounding Yarimburgaz Cave were made, and preliminary conclusions are presented in Farrand (1995). This article will deal only with the character and history of the cave infilling.

\section{Upper Cave}

The stratigraphic of the upper cave deposits is illustrated in section drawings supplied to us by Ozdogan, several of which were published by Ozdogan and Koyunlu (1986). One section is redrawn here as Figure 4, which represents a transverse section along the north faces of Trenches A.18, A.29, and A.40 (see Figure 2) as well as the east face of Trench A.29, which parallels the long axis of the upper cave. This section drawing depicts almost all of the stratigraphic units ("Levels") designated by Ozdogan, except the breccia in Level 13, which is not present in those sections. Table II is a summary of Ozdogan's unpublished descriptions of his levels as we are able to interpret them from translations graciously prepared for us by M. Ozbasaran. We have modified and amplified the descriptions in places where. we have made additional observations. Furthermore, it is now clear that Ozdogan, not being a geologist, had some misconceptions about certain features he was describing. In particular, "calcareous" veins, concretions, or particles are in most all cases actually composed largely of secondary phosphate minerals. All in all, Ozdogan's section drawings are reasonably faithful to the existing sections that we were able to revisit.

There has been much disturbance, both human and natural, of the upper 


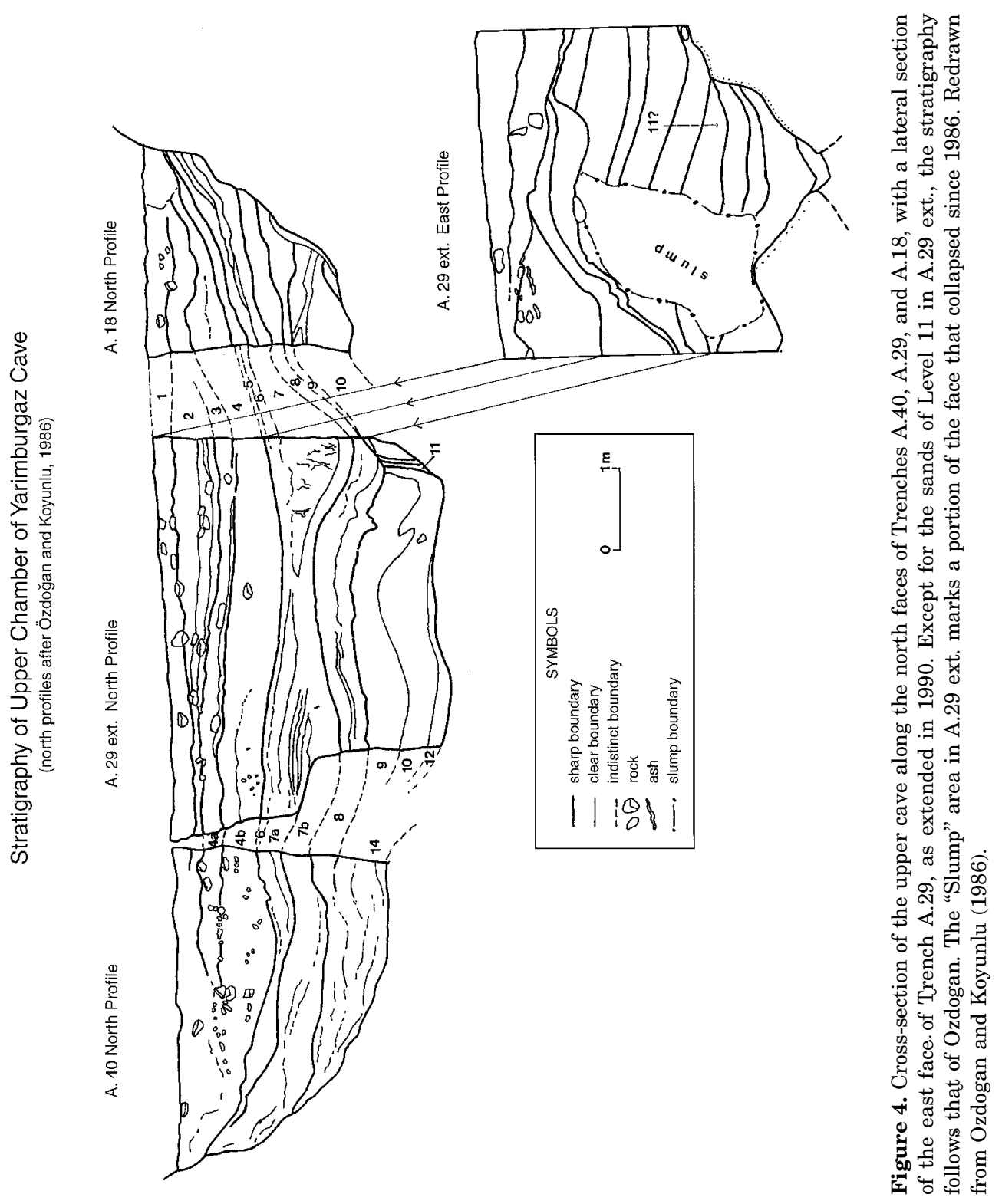


Table II. Descriptions of excavated levels, upper cave, Yarimburgaz, prepared from unpublished descriptions by M. Ozdogan as modified by our field observations. ${ }^{\mathrm{a}, \mathrm{b}}$

\begin{tabular}{ll}
\hline Level & Description \\
\hline & Trenches A.29 and A.18
\end{tabular}

Dark gray, mixed layer

Yellowish brown, fine-grained, loose, stony layer; 50-75 cm thick; Byzantine

Grayish brown, fine-grained, clayey to sandy, with small stones and abundant charcoal and mollusks; some larger stones in middle; $5-35 \mathrm{~cm}$ thick; basal $5 \mathrm{~cm}$ much richer in mollusk shell and appears to lie on a constructed floor; color changes to light orange brown in lower part; this layer is truncated by Level 1 ; Chalcolithic; ${ }^{14} \mathrm{C}=5930 \pm 110(\mathrm{GrN}-15534)$

3 Light yellowish brown, clayey to silty layer, with a little sand and few small stones; a few small charcoal fragments in general, but common on east side; some larger limestone blocks to the west, with interstitial sandy mud; $25-35 \mathrm{~cm}$ thick; artifacts rare in lower part; ${ }^{14} \mathrm{C}=$ $6880 \pm 90(\mathrm{GrN}-15528)$

4 Grayish brown, fine-grained, sandy not clayey, with medium-size rock fragments; $65-70 \mathrm{~cm}$ thick; to the west, a lens of small and medium-size rocks; contact with Level 3 marked by dark-colored laminae; some small charcoal fragments; Level 4 slopes distinctly to the north (into the cave); Chalcolithic; ${ }^{14} \mathrm{C}=7330 \pm 60$ (GrN-15529) [McMahon: Sand fraction predominantly rounded to angular quartz and phosphatic concretions, bone fragments, occasional chert, feldspar and sandstone]

5 Homogeneous mass of variable thickness, $0-5 \mathrm{~cm}$; below the top $2 \mathrm{~cm}$ the deposit is dark brown, hard and sandy [loam]; in the lower part cemented masses of iron oxide and small "calcareous" crystals, "like iron slag;" Level 5 pinches out to the west; a few potsherds [McMahon: Sand fraction predominantly rounded to angular quartz, phosphatic concretions, and occasional chert, feldspar, and sandstone]

$6 \quad$ Black with reddish brown spots and lenses, soft with very little sand; some "calcareous" concretions; $3-10 \mathrm{~cm}$ thick; slopes down and thickens to north; truncated by a pit on the south; undiagnostic flint flakes; ${ }^{14} \mathrm{C}=8110 \pm 320$ B.P. (GrN-15532)

$7 \quad$ Complex stratum, 25-70 cm thick; black to reddish brown, soft and clayey loam, with local lenses and laminae variable in color; in NE prominent vertical cracks filled with white "calcareous" residue; level slopes sharply to the north (into the cave); truncated by Level 1 in $\mathrm{SE}$; some flint cores and "Levallois" flakes; ${ }^{14} \mathrm{C}=10,000 \pm 80$ (Beta-42734) and 11,840 \pm 100 (Beta-42733) [McMahon: Upper Level 7: pale brown silty loam with small pebbles, rare charcoal; collophane-lined vugs; sand fraction is predominantly rounded to angular quartz and cemented silt or clay-size grains with embedded quartz grains. Lower Level 7: dark gray, greasy black loam, $24 \%$ organic matter.]

$8 \quad$ Transitional level more like Level 9 than Level 7, but with distinct contacts; $10-35 \mathrm{~cm}$ thick; harder than Level 7, but minor cementation only in lower lenses/laminae; small pebbles, some sand, and reddish fragments(?); sand increases in lower part; colors vary from light orange gray to black and dark brown; no stones or bones; ${ }^{14} \mathrm{C}=24,500 \pm 240$ B.P. (Beta42732)

9 Pale brown [loam], 12-55 cm thick, soft, massive level with sand, rare [quartz and chert] pebbles, and clay clods; also irregular "calcareous particles" which increase to E; truncated on the E [McMahon: Some rounded and weakly to firmly cemented silt-clay lumps; also granule-size pieces of collophane; sand fraction predominantly quartz and cemented aggregates with embedded quartz grains]

10 Fine-grained deposit with a little sand and gravel; variably (red) brown in color; 30-65 cm thick; sand increases upward and deposit is harder; more clayey, darker and softer in lower parts; some [collophane] fragments and wavy lenses; contact with Level 11 not distinct [McMahon: Medium brown to pinkish gray silt loam with collophane crusts and white lumps, probably limestone fragments with phosphatic coatings; sand fraction predominantly quartz and cemented silt-clay aggregates with embedded quartz grains, occasional chert and feldspar]

(continued) 
SEDIMENTARY INFILLING OF YARIMBURGAZ CAVE, TURKEY

Table II (Continued)

\begin{tabular}{|c|c|}
\hline Level & Description \\
\hline 11 & $\begin{array}{l}\text { Sandy deposit, over } 3 \mathrm{~m} \text { thick, largely in SE quarter of Trench A.29, but also seen in Trench } \\
\text { A.18 to the E; stratification throughout the Level dips southward (toward cave entrance) } \\
\text {-top } 50 \mathrm{~cm} \text {, orange sand with some rocks, [gravel fraction almost entirely phosphatic concre- } \\
\text { tions]; partly cemented; color changes to light grayish yellow with depth } \\
\text {-next } 50 \mathrm{~cm} \text {, uncemented reddish, sandy loam, becoming lighter in color downwards [McMa- } \\
\text { hon: at }-2.80 \text { to }-2.90 \mathrm{~cm} \text { below datum, thick unit of very clean, well-sorted fine sand; at } \\
\text { least four fining-upward cycles; occasional pebbles to } 5 \mathrm{~mm} \text { diam.; sand is subangular to } \\
\text { rounded, white, yellow, and pink quartz, chert, feldspar, and rare sandstone grains with rust- } \\
\text { colored coatings] } \\
\text { - next } 20 \mathrm{~cm} \text {, orange, lightly cemented layer } \\
\text { - next } 20 \mathrm{~cm} \text {, rather hard, cemented layer with [phosphatic] lenses } \\
\text { [additional observations in } 1990 \text { : much of the sand and gravel is cross-laminated; the lowest } \\
75-80 \mathrm{~cm} \text { of this Level is cemented gray gravelly sand overlying gray clay with white flecks] } \\
\text { [McMahon: at - } 3.30 \text { to - } 3.35 \mathrm{~cm} \text { below datum, Red silty clay with flecks of white fine-grained } \\
\text { material and MnO } \mathrm{M}_{2} \text { streaks and fragments; sand fraction predominantly cemented white and } \\
\text { orange silt-clay aggregates, some quartz] } \\
\text { - this deposit overlies and fills gaps between large fallen limestone blocks with thick weather- }\end{array}$ \\
\hline
\end{tabular}
ing rinds

[The lower part of the sequence is not exposed in Trench A.29.]

Trench A.40

12 Light yellow, "calcareous" laminations, $2-5 \mathrm{~cm}$ total thickness, hard in part, draped over the breccia of Level 13

13 Breccia; reddish brown to gray, black, and white; 50-60 cm thick, cemented mass of larger and smaller limestone rubble, with some sand in places; includes small pebbles, some manuports, and bones; two hearths observed, with pieces of charcoal(?) and burnt bone and stones; deposit concentrated in S half of A.40 and in A.39, and pinches out to W against rock wall and to $\mathrm{N}$ in middle of trench; slopes down to $\mathrm{E}$ (toward cave center) but must lie below bottom of Trench A.29

14 Dark reddish brown, (sandy) loam, soft but more compact with depth; 105-110 cm thick; includes numerous white and orange flecks (decaying limestone fragments?) and conspicuously veined with vertical and oblique white [phosphatic] streaks, which become more abundant with depth; encloses a 25-cm, angular "boulder" of stratified fine sandstone, rustycolored above grading to light brown below; a few flint artifacts, especially pebble tools, throughout this level, increasing in number to S [McMahon: Upper Level 14: Reddish brown loam matrix with pinkish white flecks; small quartz pebbles; collophane in some vugs; veins filled with yellowish white fine-grained material; rare pieces of weathered sandstone; sand fraction predominantly quartz and cemented aggregates with embedded quartz grains, occasional chert and feldspar. Lowest Level 14: Dark reddish brown silt loam, densely veined; has sticky clayey feel; black organic(?) pieces, and white flecks and white, fine-grained vein fillings; sand fraction predominantly quartz and cemented silt-clay aggregates, nodular yellow phosphatic concretions, some chert, feldspar and weathered sandstone pieces.

15 Weathered rind on bedrock surface.

a Key radiocarbon dates.for Levels 2, 3, 4, 6, 7, and 8 are included (from Farrand, 1995).

${ }^{\mathrm{b}}$ Descriptions based on Ozdogan's unpublished notes with additional information from McMahon, as noted in brackets. 
cave deposits. The most recent disturbance was by Italian film makers, who excavated a large pit in the center of the upper cave and filled it with water (Ozdogan and Koyunlu, 1986; Ozdogan, 1990, personal communication). Some 1600 years earlier a Byzantine church occupied the upper cave. The remaining evidence is largely in the form of niches, steps, chapels, arches and apses carved into the bedrock walls and ceiling (Kansu, 1970: Figures 7, 9, 10 ), as well as stone walls constructed in the transverse corridor leading to the lower cave. Undoubtedly the cave floor was also modified at that time, but any evidence is obscured by later disturbance. Still much earlier collapse and/or subsidence occurred naturally as seen in the steeply dipping strata overlying and surrounding the prominent deposit of beach sand (Level 11) that was found in Trenches A.18 and A.29 (Figure 4), discussed below. The dip angles are much too steep, near vertical in places, to be explained as original depositional slopes. The cause of this disturbance is not clear, but it may be related to underlying karstic cavities, the presence of which can only be surmised.

One striking characteristic of the upper cave deposits is the presence of a large unit of well-sorted quartz sand and fine gravel, Level 11 in Ozdogan's Trench A.29, that underlies Upper and Middle(?) Paleolithic levels. (The presence of Middle Paleolithic industries is not certain.) We enlarged Trench A.29 in 1990 revealing a much thicker deposit of sand than previously known. It is at least $3 \mathrm{~m}$ thick. The sand is cross-stratified, with bedding dipping in several different directions, typical of a beach deposit (Figure 5). There are alternations in grain size throughout the beach deposit, from well-sorted fine sand to somewhat poorly sorted sand with small gravel (up to 5-6 $\mathrm{mm}$ maximum), with variable cementation throughout the deposit. There are also intercalations of poorly sorted, loamy lenses, perhaps mud flows or slumps. Contrary to Ozdogan's interpretation, the sand rests on large angular limestone blocks, not bedrock. The blocks, as much as a meter in diameter, may be part of the rockfall deposit exposed in Trench A.40 (Level 13, "Breccia"). The surfaces of the boulders have thick weathering rinds.

No fossils at all were found in the sand and gravel to confirm its marine origin. However, its altitude, about $12 \mathrm{~m}$ above sea level, and the fact that it is overlain and truncated by deposits of relatively young age, ca. 10,00024,500 B.P. by radiocarbon, makes it a good candidate for the Last Interglacial beach. This would be Tyrrhenian in the broad sense, or oxygen-isotope Stage 5 of deep-sea chronology. The age of the beach would, therefore, be somewhere between 125,000 and 85,000 B.P., if this correlation is valid.

The strata overlying the beach deposit enclose Chalcolithic occupational debris (ceramics, mollusk shell, charcoal in Levels 2-4) and rather nondiagnostic, presumably Upper.Paleolithic, chert flakes and cores (Levels 6, 7, and probably 8), according to Ozdogan and Koyunlu (1986). Levels 6, 7, and 8, to some extent, are characterized by dark brown and black, greasy organic sediments (up to $24 \%$ organic matter), perhaps bat guano, in contrast to the dis- 
SEDIMENTARY INFILLING OF YARIMBURGAZ CAVE, TURKEY

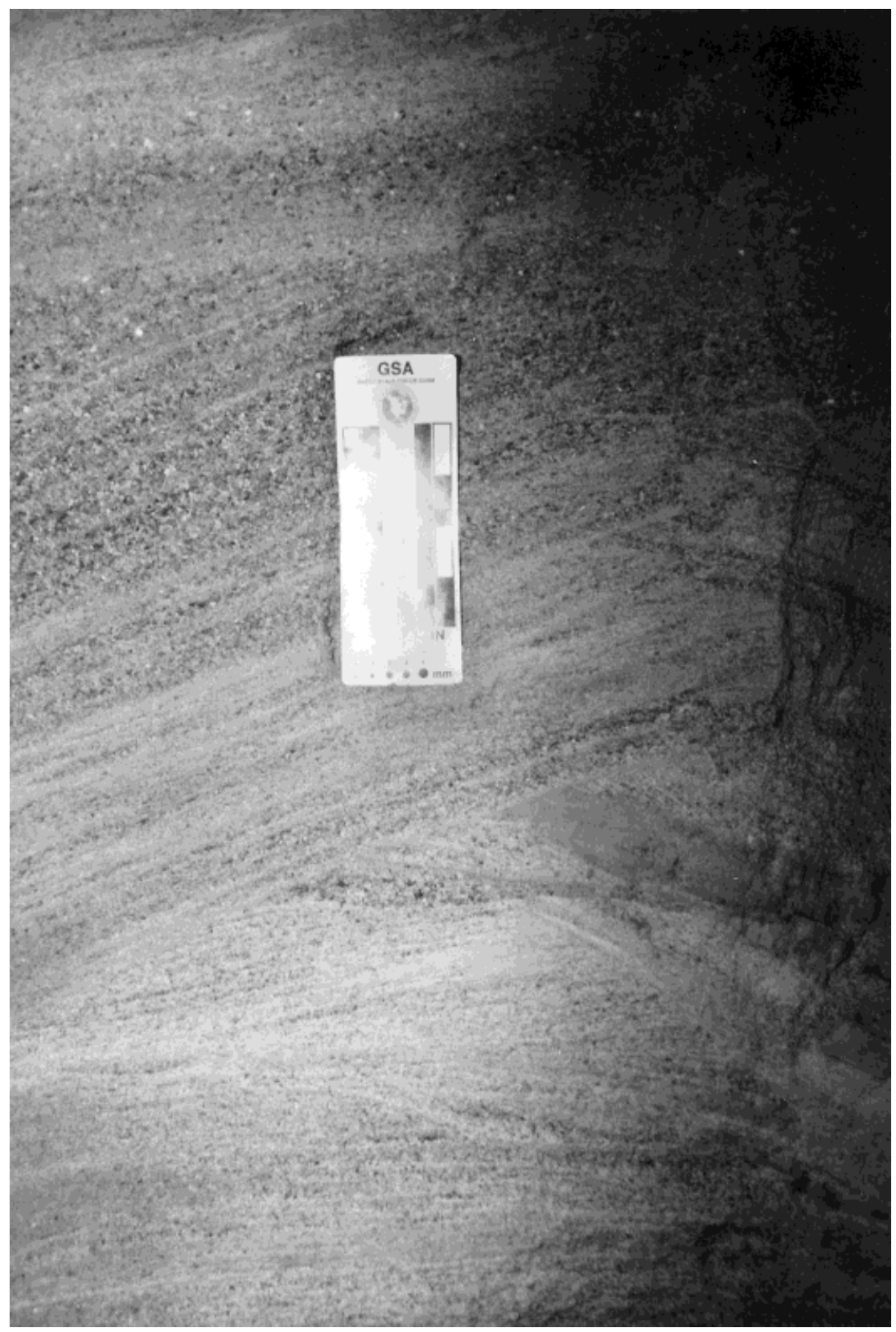

Figure 5. Close-up photograph of cross-bedded sand in Level 11, Trench A.29, upper cave. The cave entrance is to the right. 
tinctly lighter grayish to yellowish brown Chalcolithic strata. Levels 6-10 also contrast with the overlying levels in the degree of disturbance-steep dips and undulating contacts, which suggest that the cause of the natural disturbance was largely or completely dissipated before Chalcolithic times, which began ca. 8000 B.P.

Stratigraphically below the beach deposit, Levels $12-14$ are quite different in character from the overlying levels. This is best seen in Trench A.40 where Level 12 is a thin, laminated, yellowish brown crust that covers a heavy breccia (Level 13) of angular limestone blocks, which in turn overlies a dark reddish brown loam (Level 14) prominently marked by white veins and flecks of secondary phosphate mineralization. The breccia appears to be limited in extent to the area of Trenches A.40 and A.39, although it may lie below the bottom of Trench A.29. In any case, its occurrence in Trenches A.39 and A.40 is in close proximity to the opening of the transverse corridor that leads down to the lower cave, which may be fortuitous or conceivably is related to the opening or enlarging of that corridor.

Levels 12-14 are reminiscent of strata in the lower cave, described below, namely, Strata X (very rocky) through T (reddish brown loam). Archaeologically, all these levels contain similar pebble tools, manuports, and bones. Level 13 encloses several hearths and charcoal fragments, according to Ozdogan's notes, but no hearths or charcoal were detected in any level of the lower cave.

\section{Lower Cave}

A summary section has been prepared (Figure 6) that follows more or less the midline of the lower cave. The trenches are designated by capital letters followed by the year in which in trench was excavated. (The excavators did not use the letters $\mathrm{Q}, \mathrm{W}$, and $\mathrm{X}$ for the trenches because they do not occur in Turkish. They are used, however, in designating lithostratigraphic units; see next paragraph. Trench $U$ is not included here because it was very shallow over bedrock and its stratigraphy was not informative.) Trench A.71 excavated by Ozdogan in 1986 is contiguous to our Trench V-88. The level numbers shown in each trench were assigned by the excavators independently of those in the other trenches, excepting those of trenches S-89 and T-89, which were dug simultaneously and in which the correlations were immediately apparent during excavation.

We have grouped the excavation levels into lithostratigraphic units designated (from the top down) Stratum $Z$ through Stratum R, as can be seen in Figure 6. (In this case, letters $\mathrm{W}$ and $\mathrm{X}$ were used.) A summary of the stratification is given in Table I, which shows the presence or absence of a given stratum in the various trenches, as well as the abundance of artifacts recovered from each stratum in each trench. An enlarged drawing of the east and south faces of Trench A.71/V-88 in Figure 7 shows the stratigraphy described below in greater detail. 
SEDIMENTARY INFILLING OF YARIMBURGAZ CAVE, TURKEY

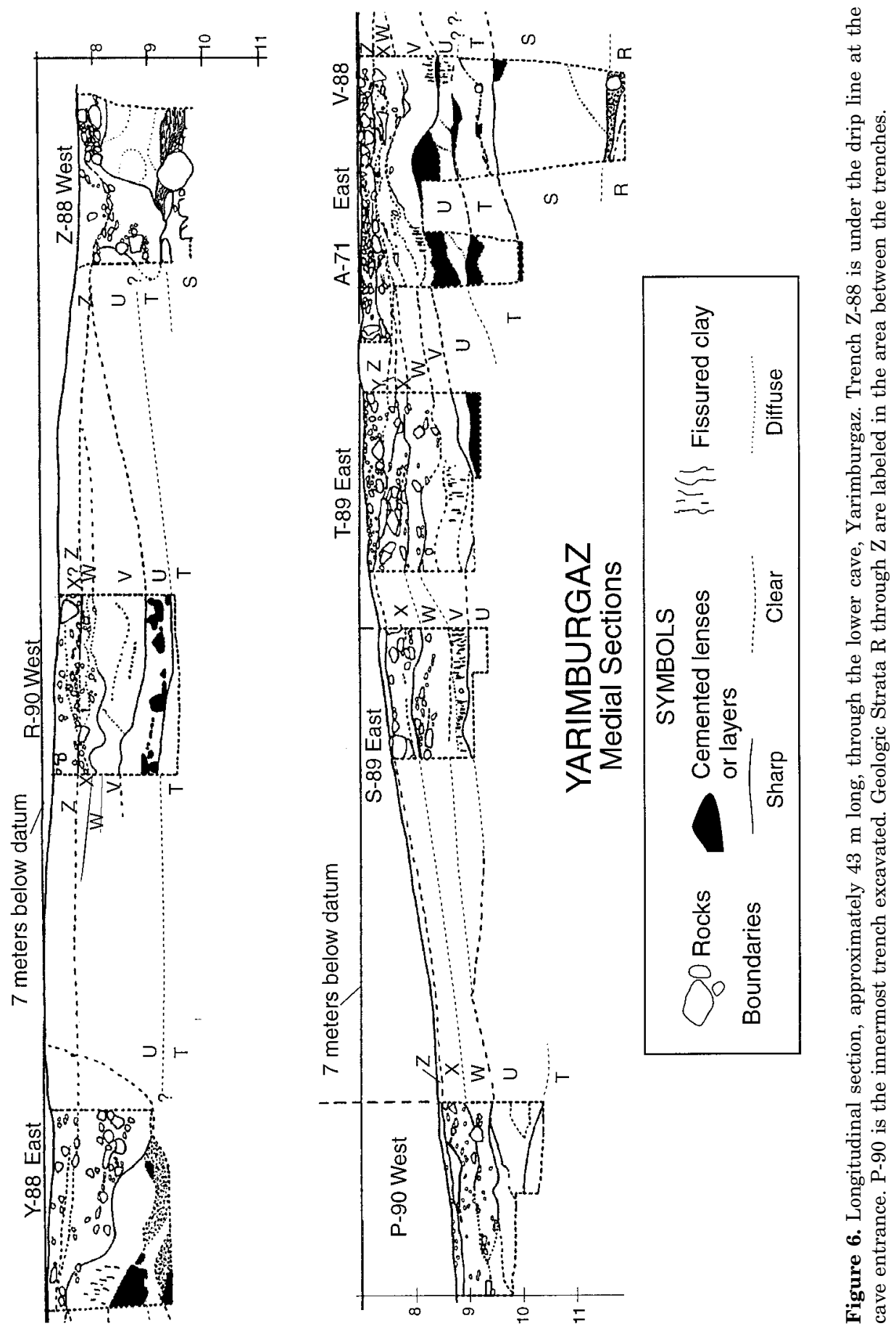

GEOARCHAEOLOGY: AN INTERNATIONAL JOURNAL 


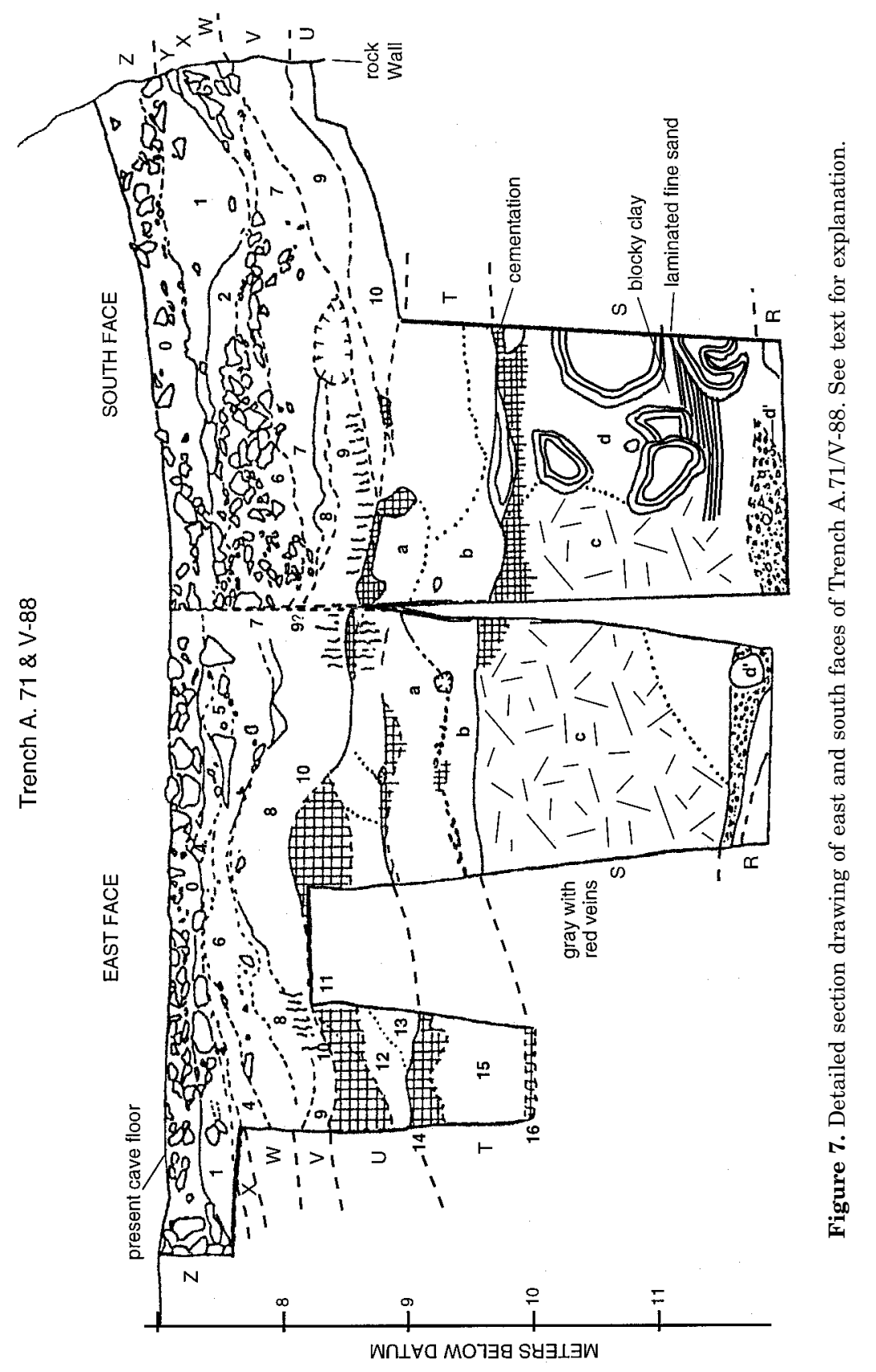


Stratum Z. Modern disturbance and fill. This heterogeneous stratum includes Byzantine to modern debris in a rather rocky sediment. Color ranges from light grayish brown to dark brown, even black, as a function of the amount of organic matter present. Rock fragments are rather angular and range up to 20 or $30 \mathrm{~cm}$ in length. This stratum is about $30-40 \mathrm{~cm}$ thick in the central and outer part of the excavated area, but it thins to $10-15 \mathrm{~cm}$ towards the cave interior (in Trenches P-90 and S-89). In Trench Y-88, however, a pit at least $2 \mathrm{~m}$ deep has been refilled with debris (Levels $0 \mathrm{a}$ and $0 \mathrm{~b}$ ) in very recent times, as seen by the presence of plastic and barbed wire. Presumably these deposits and the pit itself are the results of illicit excavations, and they are not related to the prehistoric site-formation processes. A major unconformity separates Stratum $\mathrm{Z}$ from all the underlying beds.

Stratum Y. A thin-to-discontinuous layer of soft reddish to yellowish brown loam with few rocks. It was distinguished only in the central part of the lower cave excavated area, namely in Trenches A.71, V-88, and T-89. In the latter it reaches a maximum thickness of ca. $25 \mathrm{~cm}$.

Stratum $X$. Very rocky stratum with relatively sparse, pale brown matrix, and a moderate number of bones and artifacts, especially in Trench R-90. Near the walls the rocks in this layer tend to be rather angular, but toward the center of the cave they are more rounded (corroded). These deposits reflect a period of rather intense breakdown of the cave roof, but whether the cause was climatic or due to earthquakes, or something else, is yet to be determined. As mentioned above, this rocky deposit resembles Level 13 in the upper cave, but the contemporaneity of the two deposits cannot be demonstrated.

Stratum W. Light to dark grayish brown, redder in some areas, firm loam to clay loam with scattered rocks, some with heavy weathering rinds. Stratum $\mathrm{W}$ is $40-75 \mathrm{~cm}$ thick, but it is thin to discontinuous in the front part of the cave (Trenches Y-88 to Z-88). About two-thirds of all artifacts recovered from the lower cave occurred in this stratum. An apparent unconformity separates Stratum W from Stratum V, as inferred from the change in sediment type and the presence of fissured loam in Stratum V.

Stratum V. Dark reddish brown clay to clay loam with only a few small rocks. Patches (or pebbles?) of yellow ocherous sand, presumably ripped up from underlying sediments, and isolated, well-rounded chert pebbles, 1-2 cm diameter occur throughout. This stratum is up to $1 \mathrm{~m}$ thick, especially in Trenches Y-88 and R-90, but appears to be missing in P-90, or it merges with Stratum $\mathrm{W}$ in that area. It seems to be eroded from the cave entrance (Trench Z-88). In all trenches this clay loam is conspicuously fissured, forming vertically oriented prismatic blocks resembling a pedogenic structure, but probably to be attributed to desiccation during a period of non-deposition that followed the accumulation of the loam. Artifact abundance drops off conspicuously except in Trench Y-88.

Stratum U. Light grayish brown, reddish yellow, or yellowish brown hard 
loam with numerous cemented lenses and nodules, few large rocks, but isolated chert pebbles are common. Stratum $U$ is up to $75 \mathrm{~cm}$ thick. Strong cementation in the top of this stratum appears to be by collophane, presumably derived from the decay of bone apatite. Vugs of pinkish orange, mammillary collophane occur in many places. Only 13 artifacts can be attributed to this stratum. The cemented, undulating upper surface is the basis for postulating a probable unconformity at the top of Stratum U.

Stratum T. Yellowish brown to dark reddish brown clay loam with some cemented zones, collophane vugs, and lenses of sand and gravel. The reddish brown clay loam in the lower part is relatively soft with scattered, wellrounded small pebbles common, and collophane concretions. The upper surface is marked by a cemented zone, similar to the top of Stratum U, and likewise seems to represent an unconformity. This layer is about $70 \mathrm{~cm}$ thick in Trench V-88, but was not reached in Trench S-89. In Trench T-89 excavation stopped on a hard crust, possible the top of Stratum T. It is questionably present at the bottom of Trenches P-90 and R-90.

Stratum S. Thick, complex deposit of large, heavily weathered limestone blocks (up to $1 \mathrm{~m}$ diameter) scattered throughout a reddish brown, buttery smooth clay loam that interfingers with a gritty sand facies. It is known completely only in Trench V-88, where it is just over $2 \mathrm{~m}$ thick. It seems to occur at the bottom of Trench Y-88 and in the lower half of Trench Z-88 at the cave entrance. The limestone blocks commonly measure 50-100 cm across and are matrix-supported, that is, they usually are not touching each other. Moreover, they are heavily corroded and have developed laminated weathering rinds, as much as 9-10 cm thick, apparently resulting from reaction of phosphate-bearing solutions with the limestone. In addition, the upper contact of this deposit is more or less continuously cemented (with collophane?), in places resembling travertine (which it is not), once again suggesting an unconformity at the top of Stratum S.

In Trench V-88 the sediments on the medial (east) and lateral (west) sides of the trench are quite dissimilar (Figure 7). The west wall of the trench, like that of Trench Y-88, reveals large blocks of limestone scattered throughout a very smooth reddish brown to reddish yellow clay (Unit d), but the east wall, which is situated more or less along the mid-line of the cave, has no blocks and exposes a very firm, very pale gray, gritty sediment (Unit c) crisscrossed with prominent bright red veins (or fissures with a bright red filling). The gray sediment appears to be a gleyed deposit, that is, deposited under reducing (subaqueous) conditions, and its grittiness is to be attributed primarily to incipient cementation rather than a sandy component (see below). Small chert pebbles are common in the top 15-20 cm of this layer. The bright red coloration appears to be a hematite-stained material that has filtered in along a system of pervasive cracks. The north and south walls of Trench V-88 show clearly the abrupt interfingering of this gray-and-red fissured facies and the smooth reddish brown clay of the west wall. Where the two facies meet, the 
cracks in the matrix are filled with a chalky white phosphatic material. There are also lenses of pebbles that project from the gray-and-red sediment laterally into the brown clayey facies.

The origin of this deposit and of the unusual gray-and-red alteration is under investigation by McMahon. The smooth brown clay shows some faint laminations in places, suggesting deposition in standing water; in other places, especially deep in Trench V-88 and Levels 9-11 in Trench Z-88, it gives way to a laminated, yellowish brown sandy clay loam, the laminations being highlighted by black staining, probably manganese oxide. The pebbly facies suggest that running water persisted along the midline of the cave while the fine clay accumulated nearer the cave wall.

Stratum $R$. Stratified sand, small gravel, and well-rounded chert and quartz pebbles constitute Unit $\mathrm{d}^{\prime}$ at the bottom of Trench V-88. This sediment appears to continue below the present floor of V-88 where a hole exposed a bed of chert pebbles, commonly $3-4 \mathrm{~cm}$ diameter. These stratified deposits seem to dip toward the cave entrace.

\section{SEDIMENT ANALYSIS}

Detailed analysis of the sediments is the subject of McMahon's dissertation (forthcoming), and results will be presented here only in summary fashion. Results of grain-size analysis are shown in Figures 8, 9, and 10, for the upper cave, the beach deposit, and the lower cave, respectively. Table III lists the percentages of organic matter and of acid-soluble residue for selected samples from the upper and lower caves.

The granulometric histograms of the raw (non-acid-treated) sediments show that the cave sediments have, as usual, polymodal distributions (Farrand, 1985), except the beach sands, which are mostly unimodal. Modes in gravel/granule, sand, silt, and clay sizes are commonly present, but the relative weighting of the different modes varies from sample to sample. Clay size modes (smaller than $9 \mathrm{phi}$, or $<0.002 \mathrm{~mm}$ ) are generally prominent, and the silt mode tends to be larger than the sand mode, especially in the upper cave. For the most part, however, there are not striking differences in granulometry between the upper and lower cave sediments. The $<2 \mathrm{~mm}$ fractions are largely loams or clay loams.

Since much of the sediment is slightly to strongly cemented, it is of interest to examine the original, noncemented sediment. After removal of organic matter with $\mathrm{H}_{2} \mathrm{O}_{2}$, the samples were reacted with $10 \% \mathrm{HCl}$ with mild heating. This reaction removed any $\mathrm{CaCO}_{3}$ as well as phosphate cements. As seen in Table III, the total acid-soluble fraction varied considerably, from a few percent in the sands to well over $50 \%$ in many levels. Figure 11 compares histograms of several samples before and after acid treatment, and two patterns are seen. Samples YBZ-62 and 63 from Strata U and V in the mid-depths of Trench V-88 show, after acid treatment, a reduction by half of the prominent 


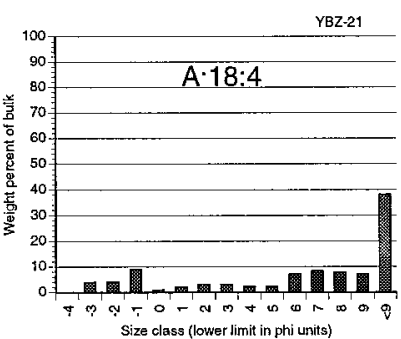

Size class (lower limit in phi units)

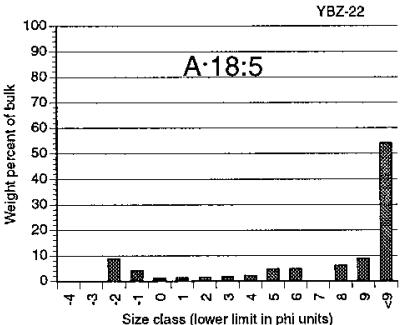

YBZ-32

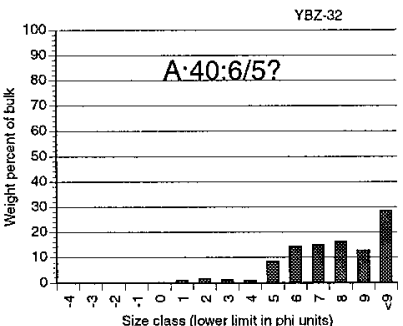

YBZ-31

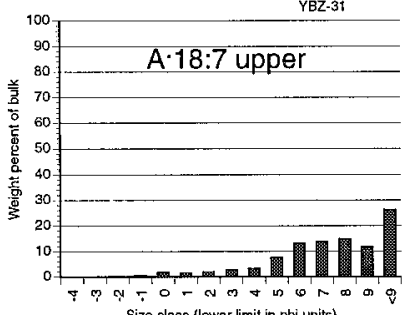

Size class (lower limit in phi units)

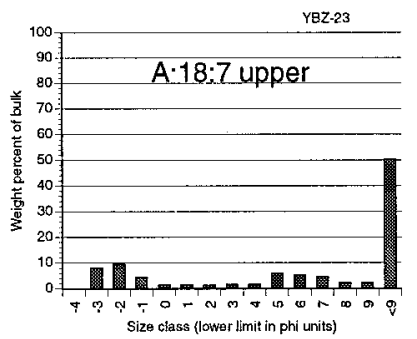

YBZ.25

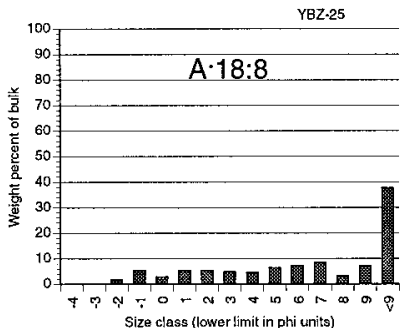

YBZ-26

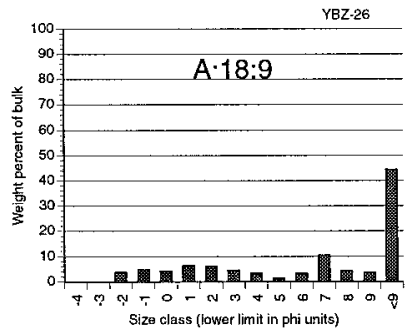

YBZ-27 decal

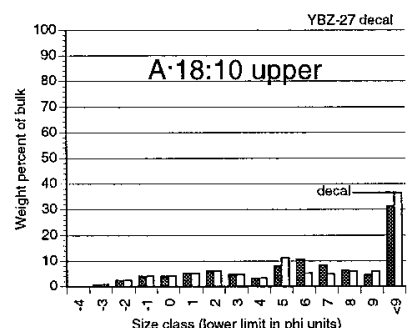

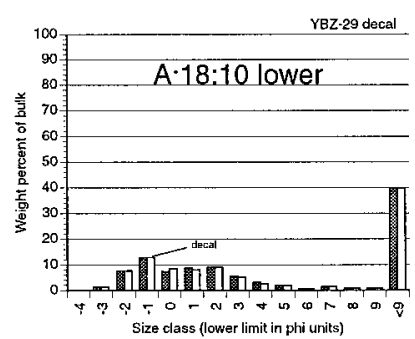

YBZ.35

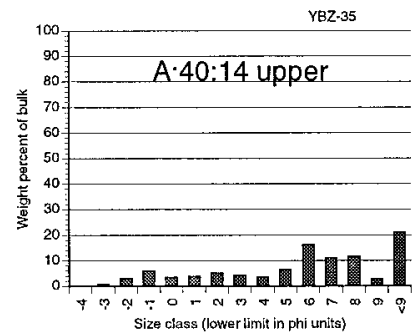

YBZ.36

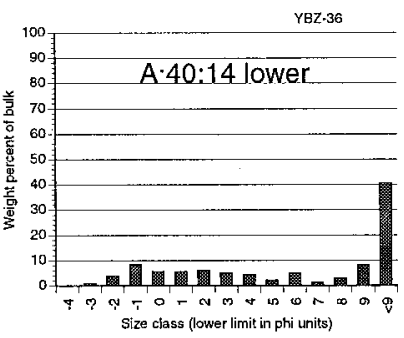

YBZ-40

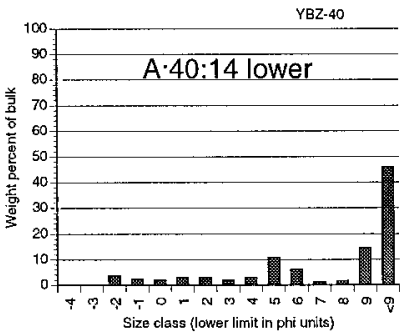

Yarimburgaz, Upper Cave Granulometry

Figure 8. Granulometric histograms of sediment samples, upper cave, Yarimburgaz, plotted at one phi intervals from -5 to -4 phi $(32-16 \mathrm{~mm})$ at the far left and $>9$ phi $(<0.002 \mathrm{~mm})$ at the far right. The stratigraphic sequence of samples moves from uppermost at the top of the left column down to the lowest at the bottom of the right column. Open histograms are acid-treated samples.

clay peak and a clear increase in the sand fraction, centered on 2 and 3 phi $(0.25-0.125 \mathrm{~mm})$. Since it is not possible that the sand actually increased, the decrease in clay implies that much of the original "clay" was in fact finely 
Size class (lower IImin in phi units)

Level 11 Sand, Trench A.29 Ext.
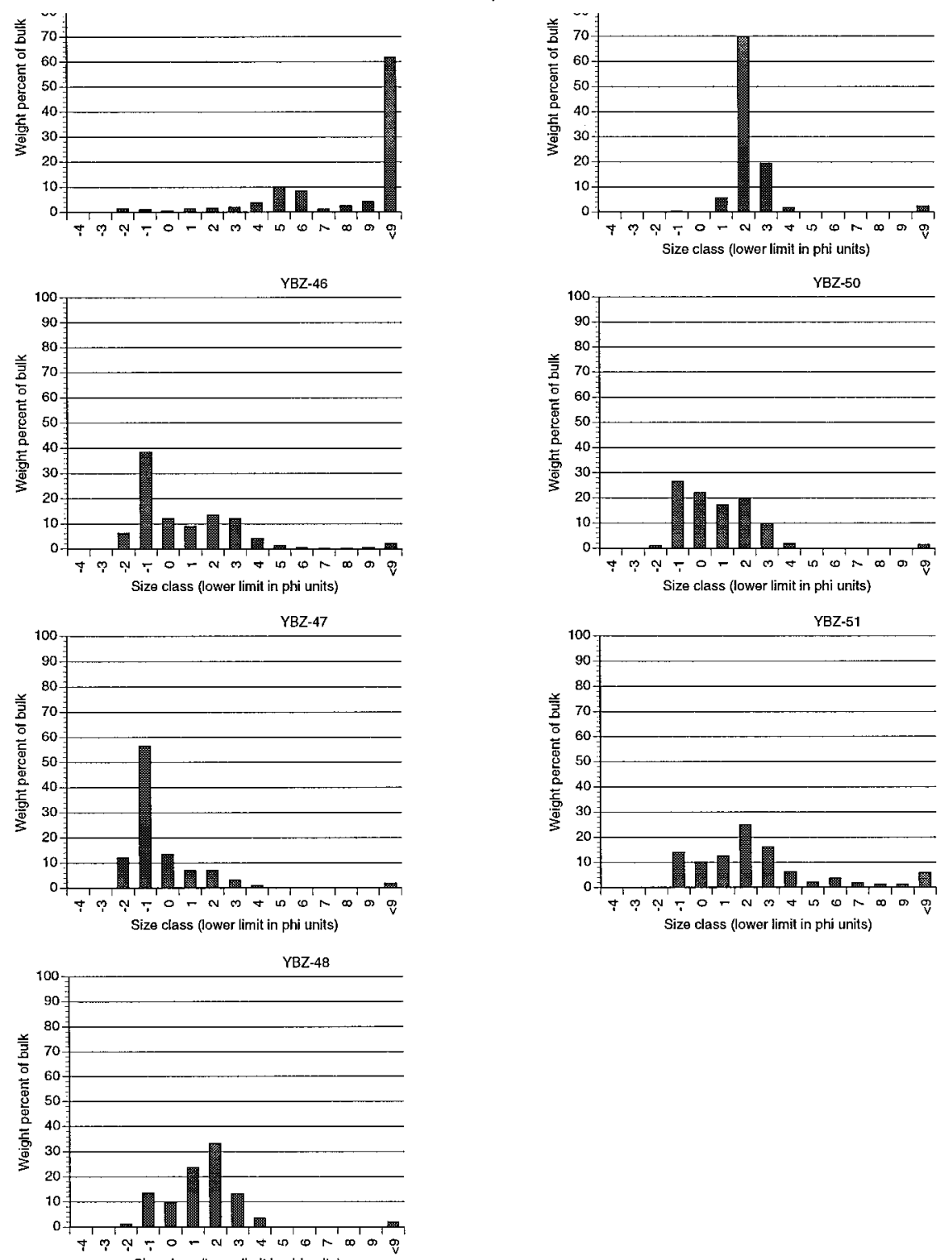

Figure 9. Granulometric histograms of Level 11, upper cave, Yarimburgaz. Conventions as in Figure 8. Except for sample YBZ-43, all these histograms show unimodal distributions of moderately to well-sorted sand. 

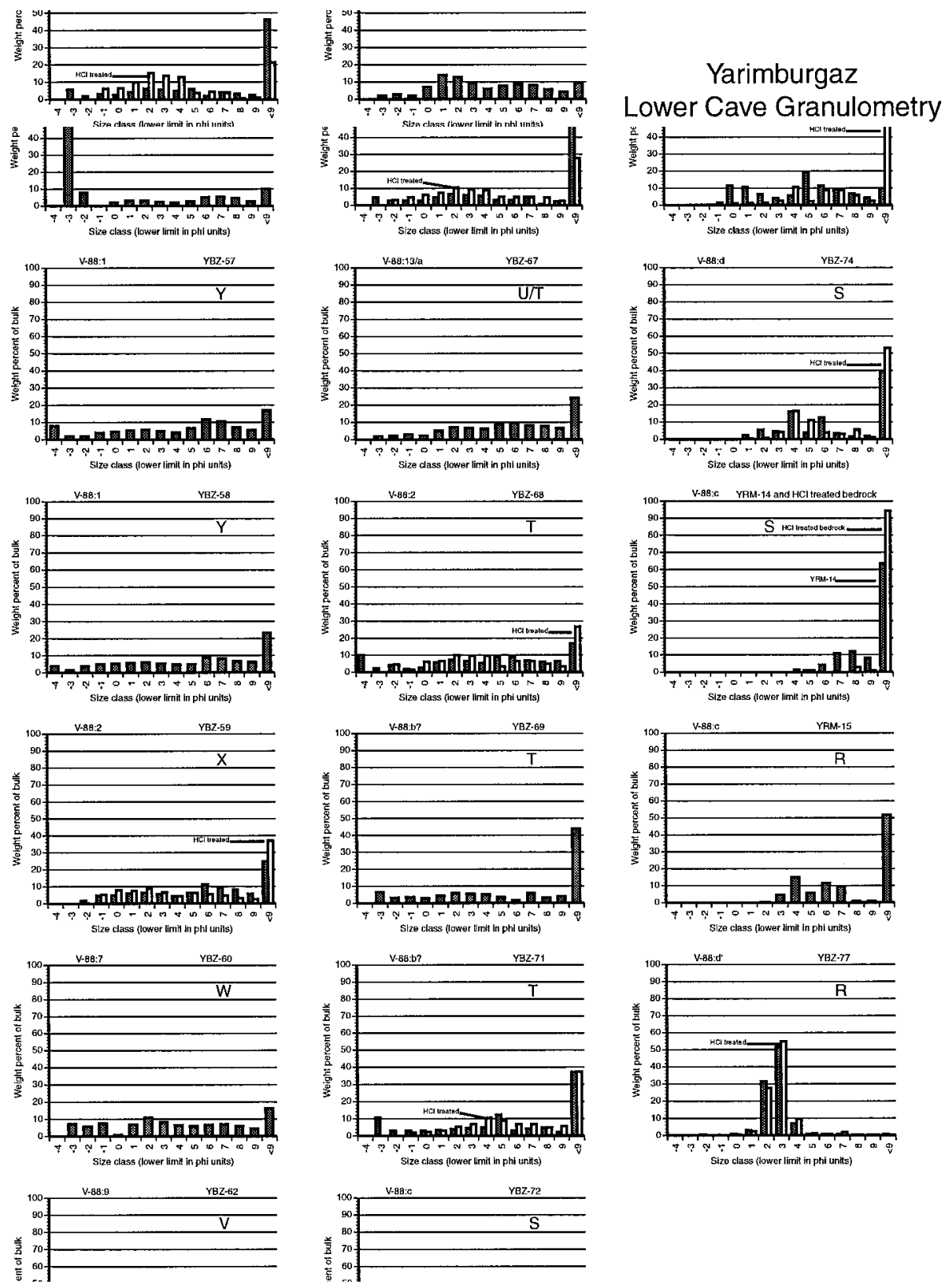

Figure 10. Granulometric histograms of sediments in the lower cave, Yarimburgaz. Conventions as in Figure 8. Both the excavation levels and lithostratigraphic units are indicated. 
SEDIMENTARY INFILLING OF YARIMBURGAZ CAVE, TURKEY

Table III. Percentages of organic matter and acid-soluble material (McMahon) in selected samples, upper and lower caves, Yarimburgaz, as determined by weight loss in $\mathrm{H}_{2} \mathrm{O}_{2}$ and warm $\mathrm{HCl}$, respectively.

\begin{tabular}{|c|c|c|c|}
\hline Sample & Level & Org. Mat. (\%) & Acid-Sol. (\%) \\
\hline \multicolumn{4}{|l|}{ Upper Cave } \\
\hline YBZ-21 & 4 & 8.0 & 38.9 \\
\hline YBZ-22 & $5 ?$ & 11.3 & 37.5 \\
\hline YBZ-32 & $6 ?$ & 14.1 & 16.4 \\
\hline YBZ-23 & 7 upper & 13.1 & 40.7 \\
\hline YBZ-31 & 7 upper & 2.1 & 28.3 \\
\hline YBZ-24 & 7 lower & 23.9 & 34.4 \\
\hline YBZ-34 & 7 lower & 18.6 & 17.7 \\
\hline YBZ-25 & 8 & 5.0 & 43.4 \\
\hline YBZ-26 & 9 & 3.0 & 21.0 \\
\hline YBZ-27 & 10 upper & 2.0 & 21.3 \\
\hline YBZ-29 & 10 lower & 1.5 & 16.5 \\
\hline YBZ-43 & $11(10 ?)$ & 1.3 & 24.6 \\
\hline YBZ-46 & $11(-2.50)$ & $<1$ & 2.9 \\
\hline YBZ-47 & $11(-2.63)$ & $<1$ & 4.0 \\
\hline YBZ-48 & $11(-2.75)$ & $<1$ & 3.8 \\
\hline YBZ-49 & $11(-2.90)$ & $<1$ & 2.9 \\
\hline YBZ-50 & $11(-3.00)$ & $<1$ & 3.5 \\
\hline YBZ-51 & $11(-3.15)$ & $<1$ & 3.6 \\
\hline YBZ-52 & $11(-3.35)$ & 3.0 & 50.9 \\
\hline YBZ-54 & $11(-4.05)$ & 1.9 & 57.8 \\
\hline YBZ-35 & 14 upper & 4.1 & 43.0 \\
\hline YBZ-36 & 14 lower & 4.0 & 38.6 \\
\hline YBZ-37 & 14 lower & 6.6 & 57.2 \\
\hline YBZ-40 & 14 lower & 6.8 & 54.1 \\
\hline \multicolumn{4}{|c|}{ Lower Cave } \\
\hline YBZ-56 & $\mathrm{Z} \quad 0$ & 3.0 & 52.1 \\
\hline YBZ-57 & $\mathrm{Y} \quad 1$ & 2.7 & 42.3 \\
\hline YBZ-58 & Y 1 & 2.4 & 36.9 \\
\hline YBZ-59 & $\mathrm{X} 2$ & 2.3 & 28.8 \\
\hline YBZ-60 & W 7 & 0.7 & 32.5 \\
\hline YBZ-62 & V 9 & 2.8 & 65.8 \\
\hline YBZ-63 & U 10 & 2.7 & 59.8 \\
\hline YBZ-67 & $\mathrm{U} / \mathrm{T}$ 13/a? & 1.3 & 26.6 \\
\hline YBZ-68 & $\mathrm{T} \mathrm{a}$ & 1.9 & 51.2 \\
\hline YBZ-69 & $\mathrm{T} b ?$ & 2.2 & 36.9 \\
\hline YBZ-71 & $\mathrm{T} b ?$ & 1.6 & 25.9 \\
\hline YBZ-72 & $\mathrm{S} \mathrm{c}$ & 2.0 & 37.0 \\
\hline YRM-14 & $\mathrm{S} \mathrm{c}$ & $13.2 ? ?$ & 18.1 \\
\hline YRM-15 & $\mathrm{S} \mathrm{c}$ & 6.8 & 17.8 \\
\hline YBZ-73 & $\mathrm{S} \mathrm{d}$ & 1.9 & 47.8 \\
\hline YBZ-74 & $\mathrm{Sd}$ & 1.6 & 33.8 \\
\hline YBZ-77 & $\mathrm{R} \mathrm{d}$ & 0.6 & 6.3 \\
\hline
\end{tabular}



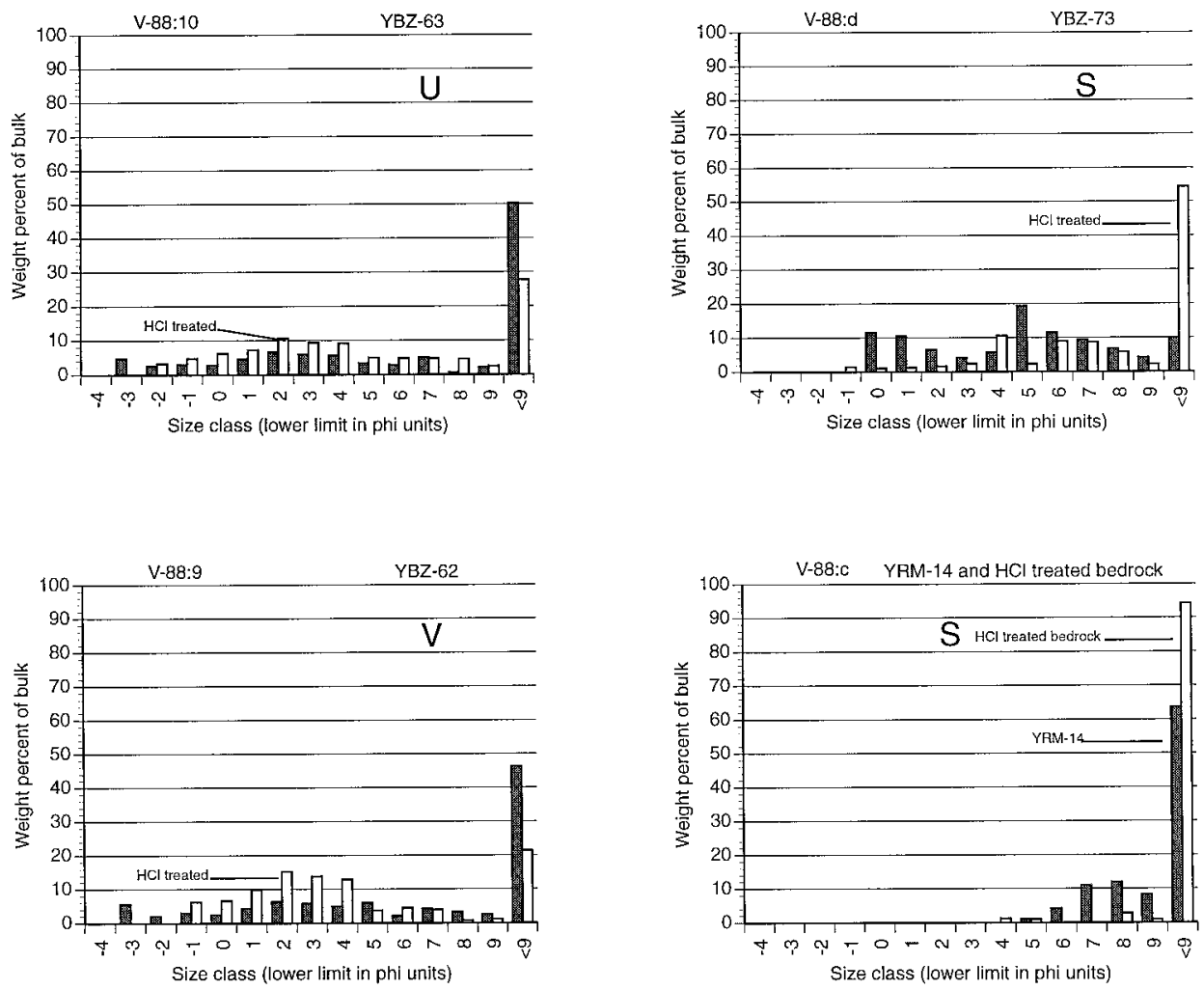

Figure 11. Comparison of histograms of raw (solid bars) and acid-treated (open bars) sediments and bedrock from Trench V-88, lower cave, Yarimburgaz. Note that YRM-14 has not been acidtreated.

divided cement, independently known to be mainly phosphate, that was solubilized. Another pattern is shown by sample YBZ-73 (the gritty gray-and-red deposits of Level c of Stratum S), from lower depths in Trench V-88. Here, after acid treatment, the clay percentage increases conspicuously, and the sand fraction almost disappears, while the silt fraction remains largely unchanged. In this case it appears that the sand fraction was composed mostly of sand-size aggregates of silt and clay-size mineral grains cemented by phosphate. Upon acid treatment the cement was removed and the embedded mineral grains are added to the silt and clay bars of the histogram.

It is of interest to note (also in Figure 11) that sample YRM-14, the very smooth clay in the lower part of Trench V-88, has a grain-size distribution very similar to the acid-treated YBZ-73. Although its acid-treated histogram is not shown, YRM-14 had much less secondary phosphate than YBZ-73, 18\% vs. $48 \%$ (Table III). One can infer, therefore, that the gray-and-red gritty 
sediments of Level c were originally similar to the smooth clay of Level $d$ before diagenetic cementation occurred.

Also in Figure 11 is a histogram of decalcified limestone bedrock from the cave, the insoluble residue of which is $>90 \%$ clay-size material with just a trace of silt. If this limestone sample is typical, one can conclude that the smooth clay of YRM-14 cannot be simply the residue of limestone weathering. Its silt component must be derived from elsewhere.

As mentioned at the outset, exotic sediments occur widely in the cave, both in the dark interior and in the outer, habitable chambers. In addition to the obvious deposits of quartz-rich sand and quartz and chert pebbles at the very bottom of Trench V-88 (Level $d^{\prime}$ ), finely laminated fine sand occurs at intermediate levels in Stratum S (Tr. V-88) and Stratum T? (Level 9) in Trench Z88, just to mention a few occurrences. McMahon has observed grains of quartz, feldspar, chert, and sandstone in the sand fractions of most of the loamy deposits in the upper cave as well. None of these sand-size minerals comes from the parent bedrock. We presume that they were washed out from the cave interior, having entered there through an as-yet-unidentified insurgence. The beach sand deposit in the upper cave, in contrast, appears clearly to have been washed into the cave through the entrance.

\section{CHRONOLOGY}

The age of the artifact assemblages in the lower cave is still largely speculative. Electron-spin resonance (ESR) results on ten Ursus deningeri teeth suggest an age between 200-220 ka (linear uptake model) and 270-390 ka (recent uptake model). A uranium-series date on a collophane crust of $160 \mathrm{ka}$ is consistent with the ESR estimate since the crust must be younger than the original deposition (Blackwell et. al., 1990, 1995). On the other hand, Howell (1990, personal communication) sees a "substantial, even close resemblance" between the Yarimburgaz faunal assemblage and other sites in central and western Europe the ages of which are much older than the Yarimburgaz radiometric dates, ranging from 350,000 to as much as 730,000 years ago. Santel (1994) finds microfaunal taxons in the lower cave sediments characteristic of those in the Russian Oka Glaciation and the following Likhvin Interglaciation, generally correlated with the Elster Glaciation and Holsteinian Interglaciation of western Europe, in turn presumably with isotope stages 8 and 7, respectively.

The cross-stratified beach deposits in the upper cave constrain the age of the Lower Paleolithic deposits in the lower cave as well as Levels 12-14 in the upper cave, if our assessment of the Last Interglacial age of the beach (given above) is correct. In that case, the lower cave deposits should be at least older than the Last Interglacial. There is a problem, however, in understanding the nature of deposition in the lower cave during the Last Interglaciation because the lower passage is some $7 \mathrm{~m}$ lower than the beach sands in 
Table IV. Sequence stratigraphy of Yarimburgaz Cave deposits.

\begin{tabular}{|c|c|c|}
\hline Sequence & Strata & Description \\
\hline Post-6 & $\begin{array}{l}1 \text { in Upper cave, } \\
\mathrm{Z} \text { in Lower cave }\end{array}$ & Byzantine overburden and modern disturbance \\
\hline 6 & $2,3,4,5,6$ Upper Cave & $\begin{array}{l}\text { Grayish brown silty clay loam with small } \\
\text { stones; Chalcolithic }\end{array}$ \\
\hline 5 & $7,8,9,10$ Upper cave & $\begin{array}{l}\text { Angular unconformity, brown, organic-rich } \\
\text { loam with some Upper Paleolithic artifacts }\end{array}$ \\
\hline 4 & 11 Upper cave & Angular unconformity, beach sand \\
\hline 3 & $\begin{array}{l}\text { Y, X, W Lower cave } \\
12,13 \text { Upper cave }\end{array}$ & $\begin{array}{l}\text { Rocky with little matrix, abundant bones and } \\
\text { artifacts }\end{array}$ \\
\hline 2 & $\begin{array}{l}\text { V, U, T Lower cave } \\
14 \text { Upper cave }\end{array}$ & $\begin{array}{l}\text { Fissured dark reddish brown loam }(\mathrm{V}) \text {, orange } \\
\text { loam (U) with collophane, reddish brown clay } \\
\text { loam with scattered pebbles }(\mathrm{T})\end{array}$ \\
\hline 1 & $\mathrm{~S}, \mathrm{R}$ Lower cave & $\begin{array}{l}\text { Strong phosphate concretion (top), interfinger- } \\
\text { ing smooth clay and gritty sediment, overly- } \\
\text { ing waterlaid sand with pebbles. }\end{array}$ \\
\hline
\end{tabular}

the upper cave. Why, then, do these sands not occur also in the lower cave? Perhaps the mouth of the lower cave was blocked by deposits that have since been eroded away. In that case, the transverse passage between the upper and lower caves must have been blocked as well, or the sands would have washed down there, too. Another possible scenario calls on active karstic streams that eroded away all traces of the beach sand and associated sediments in the lower cave, as well as any Middle or Upper Paleolithic artifacts that might have been present.

\section{SEDIMENTARY HISTORY}

The sedimentary infilling of Yarimburgaz can be subdivided into six sequences. A "sequence" is used here in the sense of sequence stratigraphy (Salvador, 1994:50-51), being a group of sedimentary beds bounded by unconformities-erosional or nondepositional surfaces-indicative of a temporal hiatus in the depositional history. The sequence stratigraphy is summarized in Table IV.

The earliest sedimentary sequence, Sequence 1, comprising Strata R and S of the lowermost 2-2.5 m in Trench V-88, begins with sorted and stratified quartz sand and pebbles. Above this level are very fine smooth clays that interfinger with gritty, cemented sediments, indicating quiet water deposits, into which large limestone blocks fell from the cave ceiling from time to time. Sediments of this sequence were also reached in the northwest corner of Trench Y-88 (Level 5) and apparently in Trench Z-88 (Level 12) at the present lower cave entrance, but not in the other trenches. The top sediments of the first sequence are strongly cemented (phosphatic), irregular in configuration, suggestive of an erosional unconformity and weathering. 
Sequence 2 (Strata T, U, and V) is registered by dark reddish brown clay loams with widely scattered quartz and quartzite pebbles. A light yellow or orange loamy horizon (Stratum U) occurs consistently in the middle of this sequence. Numerous vugs are lined with secondary phosphate (collophane) and scattered masses of sediments are firmly cemented with collophane. A firm, dark reddish brown loam with conspicuous vertical fissures (Stratum V) marks the top of this sequence. The fissures suggest desiccation of sediments on the cave floor during an extended period of time when little or no deposition was taking place, and they imply that the cave was open to the external atmosphere at the time. Level 14 in the upper cave, the dark reddish brown loam with abundant secondary phosphate, seems to fit into this sequence, as does Level 4 in Trench Z-88 at the entrance of the lower cave. Abundant animal bones and some artifacts imply the earlist human and animal utilization of the lower cave took place during the final phase of the second sequence.

The Sequence 3 sediments (Strata W, X, and Y) are quite different, being very rocky with relatively little matrix between the rock fragments. Level 13 in the upper cave may be part of this sequence. Bones and artifacts are very abundant in these sediments. Whereas the sediments of the first and second sequences are logically products of slow deposition by running water or mudflows issuing from the cave interior, the third-sequence sediments may be the results of earthquakes that detached rocks from the ceiling of the cave during a relatively short time span.

Sequence 4 is exceptional, namely in recording the influx of beach sand into the upper cave mouth. As outlined above, it is not clear why the beach deposit is not found in the lower cave. In any case, if the beach was deposited during the Last Interglaciation (isotope stage 5) and the Strata W, X, and Y in the lower cave and Level 13 in the upper cave (third sequence) accumulated around 200-210 ka (isotope stage 7) or earlier (based on ESR dates), there must be a sizable temporal hiatus of nearly $100 \mathrm{kyr}$ spanning isotope stage 6 .

Sequence 5 encompasses Levels 7-10 in the upper cave, with a scattering of Upper Paleolithic artifacts. These brown loams with scattered pebbles and organic-rich lenses overlie the beach deposits unconformably and have slumped into one or more cavities in the central part of the upper cave.

Finally Sequence 6 (Levels 2-6) is represented by pale grayish brown silty to clayey loams with some small stones and Chalcolithic potsherds, dated between 6 and $8 \mathrm{ka}$. These beds are essentially horizontal, and they truncate Levels 7-10 in an angular unconformity.

A variable thickness of modern sediments and detritus, Byzantine and younger, caps Sequence 6 in the upper cave and lies over the third sequence in the lower cave. It is usually very thin $(10-20 \mathrm{~cm})$, but deep pits with 20 thcentury debris (plastics, etc.) occur in places in both the upper and lower caves. In the lower cave the absence of Middle Paleolithic, Upper Paleolithic, and Neolithic artifacts implies a very long time gap between the third se- 
quence accumulation and modern debris that caps it. Perhaps post-Lower Paleolithic sediments were removed by erosion, but there is no clear evidence for erosion at the top of Sequence 3 sediments, except the erosion in Trench Z-88. In Trench Z-88, just inside the present drip line of the lower cave, the uppermost sediments are Byzantine and modern. They overlie a very irregular surface that appears more likely to be an erosional unconformity than a modern pit (see Trench Z-88 West in Figure 6). The absence of any artifacts in Trench Z-88 at the cave mouth, which would certainly have been an important activity area or at least the site of heavy traffic, seems to confirm the idea that erosion has removed sediments equivalent to Sequence 3 and the upper part of Sequence 2 of the cave interior, as well as any younger sediments that may have been present there.

\section{SUMMARY}

Geologic study has revealed a complex sedimentary history, beginning well before there was any evidence of human presence in the cave. The lithostratigraphic units are divided into six unconformity-bounded sequences (Table IV). Bedrock was not reached in any excavation trench in either the upper or the lower cave.

The lowest deposits encountered, pebbles and sand, were deposited by high velocity water, which then gave way to quiet water deposition of fine clays, presumably at a time when the cave was not open to the exterior, or when the cave entrance was much farther out than it is now. The middle levels in the lower cave deposits are dominated by reddish brown clayey loams with scattered grit and isolated small chert pebbles $(1-2 \mathrm{~cm})$, along with an increasing number of animal bones, largely cave bear, and stone implements imported by humans. The final evidence of Lower Paleolithic occupation of the lower cave, such as has escaped erosion, occurs in very rocky deposits, suggesting that the cave was rather wide open, perhaps similar to today. However, the exact position or configuration of the cave mouth at that time is not clear. There was considerable breakdown of the cave roof, perhaps induced by earthquakes, dropping numerous slabby limestone fragments to the cave floor.

Sometime after the Lower Paleolithic use of the cave, considerable erosion must have occurred, removing much or all of the Middle and/or Upper Paleolithic evidence in the lower cave. The next identifiable event was the influx, into the upper cave, of a large quantity of beach sand, which is tentatively correlated with a high sea level of the Last Interglaciation, or isotope stage 5. However, it is not clear why this sand did not also flood into the lower cave. Either its entrances were blocked, or the sand has been completely removed from the lower cave by subsequent erosion. During Late Pleistocene and Holocene time the upper cave was frequented by Upper Paleolithic, Chalcolithic, and finally Byzantine peoples. Presumably the lower cave was also 
occupied, but any evidence was removed or obscured by very recent human disturbances.

The authors gratefully acknowledge the encouragement and support of F. Clark Howell in all stages of this work. Financial support was largely from National Geographic Society grants to Howell. We are pleased also to recognize the excellent field work by the students from Istanbul University, under the direction of Professor Guven Arsebuk, who were very professional in carrying out the daily routine of excavation and very helpful in conveying to us the stratigraphic subtleties that they were uncovering.

\section{REFERENCES}

Arsebü, G. (1993). Yarimburgaz, a Lower Paleolithic Cave Site near Istanbul. In M. Frangipane, H. Hauptmann, M. Liverani, P. Matthiae, and M. Mellink, Eds., Between the Rivers and over the Mountains, pp. 22-36. Archaeologica Anatolica et Mesopotamica Alba Palmieri Dedicata. Rome: Universita di Roma "La Sapienza."

Blackwell, B., Schwarcz, H.P., Porat, N., Howell, F.C., and Arsebü, G. (1990). Electron Spin resonance (ESR) Dating of Ursus Teeth from Yarimburgaz, Turkey. Geological Society of America, Abstracts with Programs 22, A120-A121.

Blackwell, B., Schwarcz, H.P., and Farrand, W.R. (1995). Electron Spin Resonance (ESR) and ${ }^{230} \mathrm{Th} /{ }^{234} \mathrm{U}$ Dating at Yarimburgaz, Turkey. Unpublished manuscript in possession of the authors.

Farrand, W.R. (1985). Rockshelter and cave sediments. In J.K. Stein and W.R. Farrand, Eds., Archaeological Sediments in Context, pp. 21-39. Orono, Maine: Center for the Study of Early Man.

Farrand, W.R. (1995). Geoarchaeology of Yarimburgaz Cave, Turkey. In J.M. Bermudez, J.L. Arsuaga, and E. Carbonell, Eds., Evolucion Humana en Europa y los Yacimientos de la Sierra de Atapuerca, pp. 19-36. Junta de..Castilla y Leon, Spain.

Kansu, S.A. (1970). Yarimburgaz (Kuçukçekmece-Istanbul) Magarasinda Tưrk Tarih Kurumu Adina Yapilan Prehistorya Arastirmalari ve Tuzla Kalkolitiginde Yeni Gozlemler. VII. Turk Tarih Kongresi, Ankara 25-29 Eylul 1970, Kongreye Sunulan Bildiriler, I. Cilt, pp. 22-32.

Kuhn, S.L. (1995). Preliminary Report on Lithic Assemblage from Yarimburgaz Cave, Turkey.

.. Unpublished manuscript in possession of the authors.

Ozdogan, M., and Koyunlu, A. (1986). Yarimburgaz Magarasi. 1986 Yili Calismalarinin ilk Sonuçlari ve bazi gozlemler. Arkeolojìve Sanat, Istanbul 32/33, 4-17.

Salvador, A., Ed. (1994). International Stratigraphic Guide. 2d ed., 214 pp. Boulder, CO: International Union of Geological Sciences and Geological Society of America.

Santel, W.T. (1994). Die mittelpleistozanen Insectivora, Chiroptera, Rọdentia, und Lagomorpha (Mammalia) aus der Yarimburgaz-Hohle, westlich von Istanbul (Turkisch Thrazien). Diplomarbeit, Bonn, Rhein-Friedrich-Wilhelms-Universitat.

Schiegl, S., Goldberg, P., Bar-Yosef, O., and Weiner, S. (1996). Ash Deposits in Hayonim and Kebara Caves, Israel: Macroscopic, Microscopic and Mineralogical Observations, and the Archaeological Implications. Journal of Archaeological Science 23, 763-781.

Stiner, M.C. (1995). Taphonomy and Zooarchaeology of the Large Mammals from Yarimburgaz Cave. Unpublished manuscript in possession of the authors.

Received April 4, 1996

Accepted for publication May 2, 1997 
